\title{
Trisomy 21 and Assisted Reproductive Technologies: A review
}

\author{
Edgard Sánchez-Pavón ${ }^{1}$, Hector Mendoza ${ }^{1,2}$, Javier García-Ferreyra ${ }^{1,3}$ \\ ${ }^{1}$ EmbryoFertility Reproductive Biomedicine, Lima, Peru \\ ${ }^{2}$ University of Louisville, USA \\ ${ }^{3}$ Laboratory of Assisted Reproduction. Alcivar Hospital, Guayaquil, Ecuador
}

\begin{abstract}
Trisomy 21 is the most common genetic disorder seen among infants, and it causes spontaneous abortions, abnormal neural development and other pathologies associated with newborn development. In newborns with this trisomy, $90-95 \%$ have full trisomy, $1.4-1.9 \%$ have mosaicism, and $1-4.7 \%$ have translocations. The principal cause of trisomy 21 is advanced maternal age, in which recombination errors may occur during fetal development, age-related accumulation of damaged DNA, cohesin degradation producing the premature loss of chromosomes or sister chromatids, and alterations during the spindle formation process. The paternal age has also an effect on trisomy 21 , specifically during male aging, when there is higher risk of chromosomal breaking in spermatozoa. Epigenetics is also an important risk factor of trisomy 21 through changes in the DNA methylation process, histone modification and non-coding RNAs. Assisted reproductive technologies (ART) have emerged in recent years as a safe alternative for couples with fertility problems. These techniques, which include controlled ovarian stimulation (COS), in vitro fertilization (IVF), intracytoplasmic sperm injection (ICSI) and vitrification, decrease the incidence of aneuploidy in human preimplantation embryos, and are widely used. The following study aims to review and discuss the available literature on trisomy 21 in the field of assisted human reproduction.
\end{abstract}

Keywords: Trisomy 21, down syndrome, aneuploidy, ART

\section{INTRODUCTION}

The human genome is organized into 23 pairs of chromosomes, with approximately 21,200 protein-encoding genes that will determine the phenotypic and genotypic characteristics of an individual (Pertea et al., 2018). Chromosomal abnormalities, involving the number of chromosomes (aneuploidy) or their structure (translocations, inversions) may translate into implantation failure, miscarriages, congenital defects, malformations, non-viable embryos, etc. (Nagaoka et al., 2012; Gug et al., 2019).

One of the main causes of aneuploidy involves chromosomal nondisjunction during meiosis as part of gametogenesis and in the first stages of embryo development (Takaesu et al., 1990; Pellestor et al., 2005; Orr et al., 2015). Trisomies are the most common type of aneuploidy and are responsible for approximately $50 \%$ of spontaneous abortions, of which those involving chromosomes 16, 21 and 22 are the most prevalent (Hassold \& Hunt, 2001; Li et al., 2017).

Trisomy 21 or Down Syndrome was first described in 1866 by John Langdon Down (Down, 1995), but it was not until 1959 that Jerome Lejeune demonstrated the link between the disorder and the extra copy of chromosome 21 (Lejeune et al., 1959; Mills et al., 2011; Kurtovic-Kozaric et al., 2016). Down Syndrome is the most common aneuploidy in newborns, with an incidence of 1:700 - 16:10000 in live births (Weijerman \& de Winter, 2010; Oster-Granite et al., 2011). It presents the distinctive phenotypes of the disorder, such as brachycephaly, brachydactyly, wide hands, duodenal atresia, epicanthic folds, clinodactyly of the fifth digit, flattened nosebridge, hypotonia, mental retardation, Alzheimer's disease, short stature (Roizen \& Patterson, 2003), as well as characteristics that vary from case to case; like hypogonadism, cryptorchidism, cardiac malformations and leukemia (Coppedè, 2016).

Approximately, $95 \%$ of trisomy 21 babies have it because of maternal nondisjunction during meiosis, while $4 \%$ are due to a parental balanced Robertsonian translocation between chromosomes 13 or 14 and 21 . The remaining $1 \%$ of Down Syndrome cases are caused by postzygotic mitotic nondisjunction (Witters et al., 2011). Mosaicism in Down Syndrome, in which not all cells have trisomy 21, has been reported to occur in $2-4 \%$ of cases. Mosaic Down Syndrome can be found in two categories, according to the proportion of trisomic cells present in the individual: high grade (80-90\% trisomic cells) and low grade (0.1-38\% trisomic cells) (Hultén et al., 2013).

Presently, there are several diagnostic methods with different specificities and sensibilities to detect trisomy 21 during the prenatal stage (Rink \& Norton, 2016; Van Opstal et al., 2016; Ye et al., 2013); in addition to pre-implantation genetic testing for aneuploidies (PGT-A), which seeks to identify preimplantation embryos with abnormal chromosome numbers during IVF, and determine the risk factor of developing an aneuploidy-related disorder.

The present study pays particular attention to trisomy 21 , its causes, incidences and risks in couples undergoing assisted reproduction procedures.

\section{GENETIC BASIS FOR TRISOMY 21}

In Down Syndrome cases, $90-95 \%$ of patients have the full trisomy, $1.4-1.9 \%$ have mosaicism and $1-4.7 \%$ have translocations (Devlin \& Morrison, 2004; Shin et al., 2010; Chiang et al., 2012; Zhu et al., 2013; Iwarsson et al., 2015; Flores-Ramírez et al., 2015; Karmiloff-Smith et al., 2016).

Full trisomy ensues during chromosome nondisjunction in meiosis I (84-86\% of patients), or during chromatid segregation in meiosis II (14\% of patients) (Hassold \& Hunt, 2001; Patterson, 2009; Vraneković et al., 2012). Nondisjunction occurs when chromatids of homologous pairs fail to segregate to the opposite poles of the mitotic spindle during meiosis, and can be due to a reduction in the number of chiasmata between pairs of homologs, failure to resolve chiasmata between homologous pairs during anaphase I, and individual chromatid segregation during anaphase I, as opposed to whole chromosome segregation (Henderson \& Edwards, 1968; Hassold \& Hunt, 2001).

Mitotic errors after fertilization are the principal cause of embryonic mosaicism (Petersen \& Mikkelsen, 2000), and can occur in $15-90 \%$ of all human embryos during the preimplantation stage (Rubio et al., 2007). Depending 
on which stage the mitotic error occurs, mosaicism can be generalized or tissue-specific (Dumanski \& Piotrowski, 2012; Papavassiliou et al., 2015). Generalized mosaicism has its roots in a mitotic error before cellular differentiation, during the first day of embryonic development (65$70 \%$ of cases) (Wells \& Delhanty, 2000; Mertzanidou et al., 2013). On the other hand, tissue-specific mosaicism occurs after cellular differentiation, with an incidence of approximately $50 \%$ in embryos with 4-8 blastomeres, and $10 \%$ in the inner cell mass of blastocysts (Evsikov \& Verlinsky, 1998). Both generalized and tissue-specific mosaicism are originated by the same mechanisms: chromosomal nondisjunction, anaphase lagging (trisomy rescue), endoreplication or uniparental dissomy (Taylor et al., 2014).

In patients with mosaic Down Syndrome, the number of trisomic cells in several tissues and cells is related to the phenotypic manifestations (Modi et al., 2003; Papavassiliou et al., 2009). Respectively, mosaicism can be of high grade, in which patients have a high proportion of trisomic cells (80-90\%) with distinctive Down Syndrome characteristics; or low grade, in which there is a low ratio of trisomic cells $(0.1-38 \%)$, and the syndrome is not phenotypically perceptible (Hultén et al., 2013). The severity of genotypic and phenotypic characteristics in mosaic Down Syndrome will depend on the grade of mosaicism displayed at the cellular and histological levels, that is to say, patients with mosaic trisomy 21 could show a similar phenotype to those with non-mosaic trisomy, or even could show no phenotype at all (Papavassiliou et al., 2009).

In cases of trisomy 21 caused by translocations, the rearrangement involves Robertsonian rearrangements between the long arm of chromosome 21 (q21) and another acrocentric chromosome (Hultén et al., 2008), with chromosomes $14,15,22$ or even the homolog of 21 , being the most common (Kusre et al., 2015; Kalpana et al., 2017; Yan et al., 2017).

Full trisomy, mosaicism and translocations can originate from the alteration of the spindle assembly checkpoint (SAC), a protein complex that is responsible for regulating mitotic division via a feedback-control system (Musacchio, 2015). SAC specifically blocks the onset of anaphase through the inhibition of the anaphase-promoting complex/cyclosome (APC/C), until achieving chromosome attachment to the mitotic spindle at the metaphase plate. Once the spindle checkpoint requirements are met, the APC/C gets activated, causing the cleavage of cohesins that keep sister chromatids together (Pines, 2006; Lara-Gonzalez et al., 2012; Gorbsky, 2015). Accordingly, any disturbance to the SAC could result in the perpetuation of cell division in the presence of abnormal segregation of sister chromatids. Several other proteins and genes involved in these control mechanisms of cell division have been described, and they could be altered by factors such as aging, stress and temperature, leading to higher risk of chromosomal abnormalities (Santaguida \& Amon, 2015).

\section{MATERNAL EFFECT ON TRISOMY 21}

The process of gametogenesis in males and females has the same molecular basis, but variable predisposition to chromosomal defects. High incidence of aneuploidies are most commonly reported in oocytes, pertinent with the nature of oogenesis, which is substantially longer than spermatogenesis, occurs during both pre- and post-natal periods, and has a prolonged state of arrest during prophase I, between the fetal stage until the onset of puberty, thus increasing the probabilities of an error to occur during the segregation of homologous chromosomes (Oliver et al., 2008), or sister chromatids (Karmiloff-Smith et al., 2016).

The main causes of trisomy 21 include alterations in recombination, chromosomal nondisjunction and aging. Recombination promotes proper chromosomal orientation by the spindle apparatus to ensure subsequent separation towards opposite poles during anaphase. Absent or reduced recombination poses a risk for nondisjunction that disregards the age factor (Oliver et al., 2012). Nondisjunction of chromosome 21 can occur during meiosis I, meiosis II or during the first mitotic divisions of the embryo. Cases associated with nondisjunction during meiosis I are the most common, and may be associated with a lack of telomeric exchange, irrespective of maternal age (Lamb et al., 2005; Oliver et al., 2008; 2012). In contrast, in meiosis II, the number and localization of recombination hotspots (chiasmata) between chromosome 21 homologs are predisposed to abnormalities in an age-dependent manner, and enriched pericentrometric chromosomal exchanges are prevalent in older women (Oliver et al., 2008; Ghosh et al., 2009).

The molecular basis for the relationship between maternal age and predisposition to a trisomy 21 pregnancy is not clear. However, there is evidence that links the development of aneuploidies to advanced maternal age: recombination errors that occur during the fetal development of the mother, age-related accumulation of damaged DNA, cohesin degradation during dictyate that can lead to the premature loss of chromosomes or sister chromatids (Duncan et al., 2012) and alterations in the SAC during the spindle formation process, inevitably leading to the delay of cell division (Hauf \& Watanabe, 2004; Tanaka, 2005; Touati \& Wassmann, 2016). A weakened SAC would lead to the premature onset of anaphase prior to chromosomal attachment to the spindle microtubules, thus leading to potential errors in chromosome segregation (Galander et al., 2019). Likewise, it has been demonstrated that aging also has a negative effect in the concentration of cohesion and inhibin proteins, which are part of the SAC, and play a key role in normal cell division patterns (Duncan et al., 2012; Nabti et al., 2017).

Late motherhood is one of the main causes of infertility in women, leading to higher risks of aneuploidies during pregnancy (Allen et al., 2009). Trisomies are the most frequent chromosomic alterations observed in older pregnant women (Chiang et al., 2012). Starting at 35 years of age, the quantity and quality of oocytes begins to decrease drastically, and the risk of aneuploidies during pregnancy increases ten-fold in women over 40 years compared to women under the age of 25 years (Hassold \& Hunt, 2001). Despite being the most studied factor in the nondisjunction of chromosome 21, advanced maternal age may not be the sole culprit, thus exacerbating the need for multidisciplinary approaches that may reveal links with molecular mechanisms, environmental factors, lifestyle patterns and socioeconomic conditions (Saiyed et al., 2018).

In Trisomy 21 Mosaicism: We May All Have a Touch of Down Syndrome Hultén et al. (2013) concluded that mosaicism of chromosome 21 , in specific tissues and with variable trisomic cell proportions, is a shared characteristic in most, if not all of the general population. Considering that one may find trisomic cells in a population of fetuses with normal phenotype, the oocyte mosaicism selection model emerges, suggesting a different sexual prevalence of mosaic trisomy 21 in germinal lines, with much higher incidence in fetal ovaries than in the testes. Correspondingly, mitotic errors can emege prior to the oocyte entering meiosis, with the possibility of onset of aneuploidies in primordial follicles.

\section{PATERNAL EFFECT ON TRISOMY 21}

Spermatogenesis is a perpetual process that extends from puberty until old age. The cycle to produce one haploid spermatozoon can last 46-76 days, resulting in minor temporal tension on the gamete and lower risk of 
chromosomal abnormalities (compared to oogenesis) (Heller \& Clermont, 1963; 1964; Misell et al., 2006). Accordingly, the incidence of trisomy 21 in sperm is lower than that seen in oocytes. In addition to the discrepancy in duration of spermatogenesis and oogenesis, lower incidence of paternal trisomy 21 may also be due to the existence of a post-meiotic checkpoint in spermatogenesis, in which aneuploid spermatids or spermatozoa are arrested (Uroz \& Templado, 2012).

Nondisjunction in spermatogenesis and oogenesis can be due to similar mechanisms, such as failure to resolve chiasmata between homologous chromosomes during anaphase I, absence of chiasmata between homologues that prevents appropriate chromosomal segregation, and the premature separation of sister chromatids during anaphase (Jones, 2008; Fragouli et al., 2011).

During spermatogenesis, the most commonly occurring abnormalities involve dissomies in secondary spermatocytes, as opposed to trisomies in primary spermatocytes. Futhermore, there is evidence of a higher number of chromosomes without recombination hotspots during meiosis I, which is associated with abnormal segregation of chromosome 21 (Oliver et al., 2009), and errors during meiosis II (Uroz \& Templado, 2012). Secondary spermatocyte disomy is primarily caused by the absence of chiasmata of meiosis I chromosomes and errors during segregation of bivalents with reduced numbers of chiasmas, thus resulting in diploid spermatozoa and aneuploid embryos (Egozcue et al., 2000; Munné et al., 2007; Magli et al., 2009).

According to Iwarsson et al. (2015), the probability of a trisomic pregnancy caused by a spermatozoon with twice as many chromosomes 21 is less than 1 in
800 pregnancies. Contrastingly, the percentage of aneuploid embryos is higher in male-factor infertile patients (oligoasthenoozoospermia or non-obstructive azoospermia) than in infertile patients with a normal male factor (Magli et al., 2009).

The link between paternal age and trisomy 21 has not been fully elucidated and continues to be controversial. However, studies by Carrasquillo et al. (2019) and Thompson (2019) showed that there was no significant association between advanced paternal age and trisomy 21; whereas Sotonica et al. (2016), García-Ferreyra et al. (2018), and Corona-Rivera et al. (2019) demonstrated that older fathers have a higher risk of Down syndrome pregnancies compared to younger fathers (Figure 1). Likewise, Templado et al. (2011) and Sotonica et al. (2016) revealed that paternal age is associated with an increased risk of chromosomal breaking in spermatozoa, leading to translocations commonly associated with trisomies.

When the grade of mosaicism in germline cells of male fetuses is evaluated, it is apparent that, in comparison to germline cells of the ovary, the percentage of cells with trisomy 21 is low. This finding is associated to stricter and selective control during cellular division in the testicles (Hultén et al., 2008; 2010), thus resulting in higher incidences of maternal influence in Down syndrome cases. On the other hand, unlike individuals with more serious cases of trisomy 21 who are considered infertile, individuals displaying mosaicism may pass on their condition or even be the direct cause of a serious trisomy 21 pregnancy. Nevertheless, more studies that illustrate the molecular mechanisms behind mosaicism in both paternal and maternal backgrounds are needed to corroborate such findings.

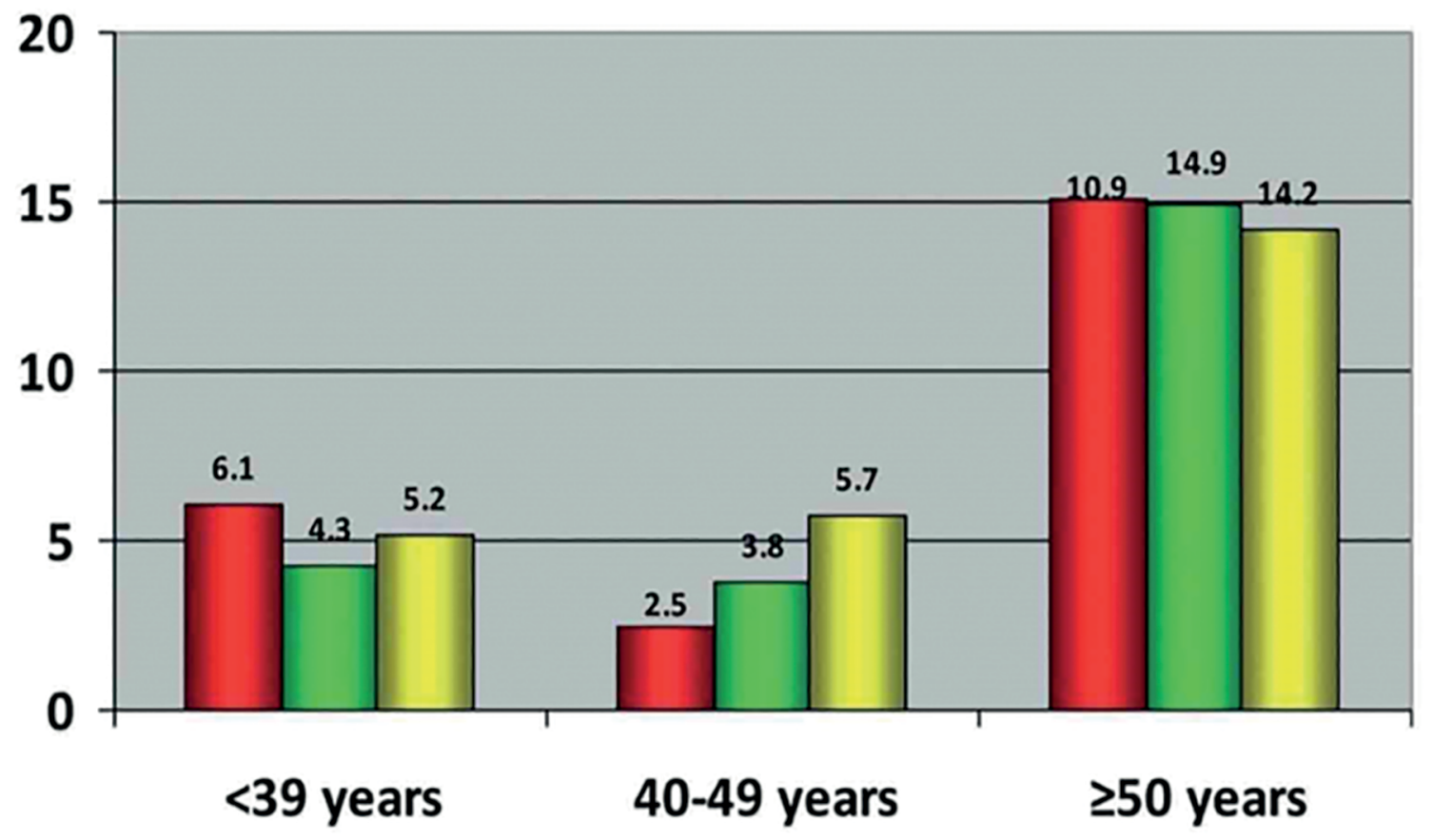

口 Trisomy 21 - Trisomy 18 Trisomy 13

Figure 1. Percentages of embryos with trisomy 21,18 and 13 in men $\leq 39$ years, $40-49$ years and $\geq 50$ years. Source: García-Ferreyra et al. JBRA Assist Reprod. 2018. 


\section{EPIGENETIC EFFECT ON TRISOMY 21}

Down syndrome is a gene expression disorder, involving 200-300 genes encoded in chromosome 21 (Hattori et al., 2000). The presence of an extra chromosome (partial or total) could lead to gene over expression (Weber et al., 2016). According to the "gene dosage effect" hypothesis, some of the features of Down syndrome could be directly explained by the dosage imbalance of HSA21 genes (Lyle et al., 2009). The extra chromosome 21 imposes a trans-acting effect in other chromosomes that cause epigenetic changes, including differential CpG methylation in specific sets of downstream target genes (Do et al., 2017).

Epigenetics encompasses the understanding of heritable changes in gene expression or cellular phenotype, without changing the underlying DNA sequence (Bird, 2007; Deans \& Maggert, 2015), with the principal mechanisms to alter DNA expression being methylation and acetylation. DNA methylation is related to the addition of a methyl group to cytosine bases, generally located in CpG dinucleotides (Ball et al., 2009), by the DNA methyltransferase (DNMT) family of enzymes (DNMT1, DNMT3A and DNMT3B); whereas demethylation is mostly catalyzed by the ten-eleven translocation (TET) enzymes (TET1, TET2 and TET3) (Gensous et al., 2019), by action of DNA methyltransferase enzymes (DNMT1, DNMT3A Y DNMT3B) (Ciccarone et al., 2018a).

Gensous et al. (2019) have reported marked DNA methylation alterations in cells of patients with trisomy 21 , being hypermethylation and genome-wide perturbance of DNA methylation the most prevalent findings. Likewise, low levels of TET enzymes, which may cause hypermethylation through decreased DNA demethylation have been reported (Jin et al., 2013; Ciccarone et al., 2018b), in addition to the disturbance of the metabolic network that produces S-adenosylmethionine (SAM); which is crucial in DNA methylation as the universal donor of the methyl group (Ball et al., 2009; Obermann-Borst et al., 2011; Obeid et al., 2012).

Several studies have suggested an epigenetic origin as a possible cause to the different pathologies in Down syndrome patients, involving changes in the DNA methylation process, histone modification and non-coding RNAs, which have an important role in gene expression in immune and central nervous systems diseases (Teipel \& Hampel, 2006; Jones \& Lane, 2013; Sailani et al., 2015; Wiseman et al., 2015). Patients with trisomy 21 show premature aging (Patterson \& Cabelof, 2012), particularly in the immune and central nervous systems (Lott \& Head, 2005; Teipel \& Hampel, 2006). Several biological hallmarks of aging have been established, such as DNA damage buildup (LópezOtín et al., 2013), telomere shortening (Jenkins et al., 2006), loss of the proteostasis network (Aivazidis et al., 2017), oxidative stress and mitochondrial disfunction (Pagano \& Castello, 2012). These biological hallmarks, along with the epigenetics markers represent a new type of molecular marker of aging, described as a modern 'epigenetic clock' and based on DNA methylation levels (Horvath, 2013).

\section{ASSISTED REPRODUCTION AND TRISOMY 21}

\section{Ovarian stimulation}

In the last years, there has been a substantial increase in the age in which women decide to get pregnant, by professional or personal decisions, and this delay reduces their possibility to achieve a spontaneous pregnancy and carry a healthy baby for a full term (Munné et al., 1995; Nybo Andersen et al., 2000; Radoń-Pokracka et al., 2019). As a result, more and more women are turning their attention to assisted reproduction alternatives (Mills et al., 2011). Achieving an advanced-age pregnancy; however, this also increases the onset of chromosomal abnormalities like trisomy 21. In Europe, the last decade has been witness to a $10 \%$ increase in trisomy-21 pregnancies, all linked to higher maternal age (Loane et al., 2013).

Controlled ovarian stimulation (COS) with exogenous urinary or recombinant gonadotropins maximizes the number of oocytes yielded to overcome the high rate of attrition of gametes and embryos during an IVF treatment. Check (2007) suggested that COS could influence oocyte maturation and the completion of meiosis; potentially mediating chromosomal aneuploidy and mosaicism. However, all prior human studies investigating the effect of COS on embryonic aneuploidy screening a limited number of chromosomes and using fluorescent in situ hybridization analysis of blastomeres from day-3 embryos (Baart et al., 2007; Weghofer et al., 2008), have been demonstrated to have suboptimal diagnostic accuracy.

The advent of better assisted reproductive technologies has seen a rise in the use of blastocyst cultures and trophectoderm biopsies in embryology laboratories worldwide. These techniques enable natural embryonic selection through the extended culture of the blastocyst or the screening of several trophectoderm cells and 24-chromosomes. When taking into consideration the possible negative effects of COS during the aforementioned techniques, Sekhon et al. (2017) and Thorne et al. (2019) did not report a significant difference in aneuploidy rates. Likewise, Barash et al. (2017) showed that different doses of gonadotropins had no effect on the clinical pregnancy of women undergoing an IVF procedure. Finally, Wu et al. (2018) evaluated the effect of gonadotropins in two groups of patients: $<35$ and $\geq 35$ years old, and showed that the aneuploidy rate was $40 \%$ in younger patients and $59 \%$ in older patients. Higher doses did not increase the aneuploidies rates in blastocysts within the same age group.

\section{In vitro fertilization}

The frequency of aneuploidies in human preimplantation embryos generated during IVF oscillates between $56 \%$ and $84 \%$ (Fragouli et al., 2014), and its occurrence is related to gamete quality (Coates et al., 2013), maternal and paternal ages (Dailey et al., 1996; Fragouli et al., 2014; García-Ferreyra et al., 2015; 2018) and not with the procedure itself. Several authors have showed that the prevalence of aneuploid pregnancies in IVF procedures are similar to those observed in spontaneous pregnancies (Bingol et al., 2012; Pendina et al., 2014; Qin et al., 2013).

Morphological examination of oocytes during an IVF is subjective and does not allow the true assessment of the cytoskeleton and general physiology of the oocyte. Accordingly, it has been previously suggested that poor morphological quality may be related to the emergence of aneuploidies during embryonic development (Dolgushina et al., 2015; Lubis et al., 2017). Furthermore, depending on maternal age, the quality of the oocyte differs, which in turn may increase the probabilities of chromosomal abnormalities (Cimadomo et al., 2018). Aneuploidies have also been reported to be linked to meiotic arrest and cessation of gamete production in men, resulting in oligozoospermia or even azoospermia (Andreescu et al., 2016); and although trisomy 21 could have paternal origins (albeit with a lower incidence), alterations in the quality of the seminal sample may favor a higher incidence of aneuploid embryos (Coban et al., 2018).

Advanced age in couples may represent a major cause of infertility and a reason to explore assisted reproduction treatments to achieve pregnancy. It is well established that aneuploidy is present in embryos from infertile patients and dramatically increases with maternal age, from $73 \%$ in patients 35 years or younger, to $87 \%$ in patients 41 years or older (Fragouli et al., 2014). In regards to paternal age, García-Ferreyra et al. (2018) evaluated the 
aneuploidy rates in embryos obtained from egg donations, showing that men $\geq 50$ years old generated significantly more aneuploidy embryos compared to younger men; and $10.9 \%$ of their embryos had trisomy 21 compared to $6.1 \%$ and $2.5 \%$ in men $<39$ years and $40-49$ years, respectively. Therefore, advanced age in women and men significantly reduces the probability to obtain at least one euploid embryo (Ata et al., 2012), and increases up to $91.7 \%$ the possibility to obtain aneuploidy embryos during in IVF procedure (Su et al., 2016).

Assisted reproduction techniques are based on the insemination of occytes in the laboratory setting, being IVF and ICSI the most commonly sought after procedures. When comparing blastocysts obtained from IVF and ICSI treatments with normal male factor, De Munck et al. (2020) found similar euploid rates in both techniques (IVF: 49\%; ICSI: 44\%); and when evaluating the incidence of aneuploidies in chromosome 21, the authors showed that $25.8 \%$ of embryos from IVF were trisomic, compared to $20.3 \%$ of embryos from ICSI. Currently, there is no published evidence associating ICSI with the incidence of trisomy 21.

There are several factors (maternal and paternal age, gametes quality, cause of infertility, etc) that could increase the percentages of embryos with trisomy 21 generated during an IVF treatment and thus, to cause a higher prevalence of trisomy 21 babies. However, many of these trisomic embryos do not implant or are eliminated early after implantation. In cases of fertile younger women, Munné et al. (2017a) analyzed the external factors that affect euploidy in embryos from egg donor cycles made in different fertility centers in USA, demonstrating that the aneuploidy rates oscillate between $17-60 \%$.

\section{Cryopreservation}

The cryopreservation of oocytes and embryos is a technique that, due to its utility and popularity, plays an important role in assisted reproductive technology (Nagy et al., 2014). Ever since the first pregnancy and subsequent birth of cryopreserved oocytes and embryos (Trounson \& Mohr, 1983; Zeilmaker et al., 1984; Chen, 1986), different protocols have emerged, differing in the type and concentration of the cryoprotectant, equilibration time, cooling rate and cryopreservation devices. Nonetheless, two of these protocols have been referenced the most in the last decades: slow freezing and vitrification (Edgar \& Gook, 2012). Cryopreserving blastocysts via vitrification has improved success rates compared to slow freezing (AbdelHafez et al., 2010), with different survival rates (93\% vs. $73 \%)$, implantation rates (33\% vs. $26 \%$ ) and clinical pregnancy rates (65\% vs. 55\%) (Bernal et al., 2008). Thus, vitrification is highly preferred and has seen a dramatic increase in assisted reproduction laboratories worldwide (Levi-Setti et al., 2016).

During the processes of freezing and thawing, the oocyte undergoes physical and physiological changes (Gardner et al., 2007) that may induce alterations in the segregation of chromosomes during meiosis II (Nottola et al., 2007; Noyes et al., 2009). Huang et al. (2007) demonstrated that the integrity of the mitotic spindle during chromosome alignment in cryopreserved mice oocytes was less compromised when vitrification was used. However, both slow freezing and vitrification had similar percentages of embryonic aneuploidies. In humans, it has been shown that vitrification does not increase DNA or mitotic spindle damage in oocytes, nor aneuploidies in the embryo (Forman et al., 2012; García et al., 2011; Zhang et al., 2015).

Oocyte vitrification and long term storage does not affect the percentage of euploid blastocysts obtained after an IVF or ICSI cycle (44.5\% vs. $47.6 \%$ in fresh oocytes) (Goldman et al., 2015). In the same manner, cryopreservation enables the buildup of a higher number of oocytes to increase the number of available euploid embryos in a single cohort (Chamayou et al., 2017), and when vitrification is chosen due to social connotations in younger women, the risk of trisomy 21 related to maternal age decreases, as seen in cases that use oocytes obtained from a cryobank (Cobo et al., 2010).

\section{TRISOMY 21 DIAGNOSIS}

The diagnosis to determine if an individual has an extra copy of chromosome 21 can be achieved in three different stages. In the postnatal stage, a confirmatory diagnosis is based on the anatomical characteristics and on the blood karyotype of the patient. In the prenatal stage, non-invasive studies may be implemented, such as hormone and DNA analysis of the mother (Ho et al., 2003; Yang et al., 2003; 2006), but a more accurate diagnosis requires invasive procedures, such as amniocentesis, chronic villus sampling or umbilical blood sampling. On the other hand, assisted reproduction techniques have enabled the cytogenetic evaluation of embryos prior to implantation, thus making embryonic selection more efficient (Munné et al., 2004) when compared to embryos selected by their morphological quality (up to $80 \%$ of blastocysts with "adequate" morphology can present trisomy 21) (García-Ferreyra et al., 2018). In the preimplantation stage and during the first days of embryonic development, a biopsy of 1 or few embryonic blastomeres can be taken (one cell at day 3 or 5-10 cells trophoblast at days 5-6) and an embryonic culture based on IVF techniques can be made.

In the last years, the preimplantation genetic testing for aneuploidies (PGT-A) with blastomere biopsy (cleavage stage) has been replaced by trophectoderm biopsy (blastocyst stage), due to problems associated with single cell analysis, both technical (e.g., high rate of amplification failure), and biological as chromosomal mosaicism, namely, the presence of cells with different karyotypes within the same embryo, seems to reach its highest level at this stage of preimplantation development (Voullaire et al., 2000; Bielanska et al., 2002). In regards to clinical outcomes, there are several studies showing the ineffectiveness and potential impairment of cleavage stage biopsy, including the review and meta-analysis of Mastenbroek et al. (2011) which highlighted the failure of preimplantation genetic screening when conducted by 9 chromosome FISH on biopsied blastomeres.

PGT-A with blastocyst stage biopsy strategy was reported for the first time by de Boer et al. (2004) and the first live births were reported by Kokkali et al. (2005) and McArthur et al. (2005), and compared to biopsy at cleavage stage, the power of this strategy resides in its higher technical and biological robustness, lower influence of procedural errors and lower impact of mosaicism on the molecular analysis. Studies by Scott Jr et al. (2012) comparing the ongoing pregnancy between trophectoderm and blastomere biopsy approaches, confirm the higher reliability of blastocyst stage analysis with respect to cleavage stage one $(48.2 \%$ versus $29.2 \%, p=0.001)$.

In regards to amplification technologies to detect aneuploidies, many platforms are used for PGT-A as Single-Nucleotide Polymorphism (SNP) testing, array-based Comparative Genomic Hybridization (aCGH), and Next-Generation Sequencing (NGS). Each platform has its own advantages and limitations. SNP array detects segmental mutation, parental origin of monosomy and trisomy, DNA fingerprinting to prevent misdiagnosis caused by contamination, and mosaicism but it is more technically complex and needs a longer turnaround time. On the other hand, aCGH can 
also detect unbalanced translocation from parental Robertsonian, reciprocal translocation carriers and mosaicism, but with a lower sensitivity than NGS. NGS platforms have become increasingly popular in PGT-A because of their high throughput, their ability to precisely detect mosaicism and segmental mutation, and their capability of concomitant PGT-A and monogenic disorders. Huang et al. (2016) validated the NGS platform in blastocysts, demonstrating that among the aneuploid embryos identified by aCGH, re-biopsied and rechecked by NGS showed high positive $(97.6 \%)$ and negative (99.6\%) predictive values of aneuploidy assignment compared with the SNP array. Additionally, Friedenthal et al. (2018) showed that the use of NGS increased the ongoing pregnancy and live birth rates of a single frozen-thawed euploid embryo compared to aCHG.

Mosaicism in embryos is characterized by the presence of two or more genetically distinct cell lineages, typically one with a chromosome abnormality and the other showing a normal chromosome constitution (Spinella et al., 2018). Recent studies have suggested that diploid/aneuploid mosaicism in blastocysts is relatively uncommon (4-6\%) and a preferential segregation of mosaicism did not occur in the inner cell mass of the trophectoderm (Capalbo \& Rienzi, 2017; Capalbo et al., 2017). In regards to reproductive outcomes after transfer of mosaic blastocysts, Munné et al. (2017b) showed lower implantation rates (53\% versus $70 \%$ ) and higher miscarriage rates (25\% versus $10 \%$ ) compared to euploid blastocysts, but the authors also showed that $41 \%$ of mosaic embryos can produce an ongoing implantation.

Currently, non-invasive preimplantation genetic testing has become more relevant and successful, with 80-90\% success rate as it is concordant with embryonic biopsies (Liñán et al., 2018; Capalbo et al., 2018) that analyses embryonic DNA present in the culture medium. However, due to its novelty, further studies are required to evaluate its concurrence with the detection of genetic abnormalities like trisomy 21 (PGT-A can confirm an aneuploidy with up to $96 \%$ concordance) (Victor et al., 2019).

\section{CONCLUSION}

In humans, the trisomy 21 or Down Syndrome causes spontaneous abortions, abnormal neural development and other pathologies associated with newborn development. Depending on the severity of the genetic insult, the disorder can present itself as: a full trisomy (every cell presents a full extra copy of chromosome 21, the most common type), a translocation (one of the three chromosomes 21 is attached to another chromosome) or mosaicism (some cells have 3 copies of chromosome 21 and some are normal). However, unless a genetic study is done on the patient, telling these three types apart cannot be done phenotypically. The literature on trisomy 21 is vast and has highlighted advanced maternal and paternal ages, in addition to epigenetics, as important risk factors for the occurrence of this disorder. Accordingly, assisted reproductive technologies have emerged as important alternatives for infertile couples to achieve a healthy pregnancy. To date, there is no evidence that these technologies may increase the risk of genetic disorders like trisomy 21 . Nevertheless, it is highly recommended to pair them with the appropriate genetic studies for the early detection of aneuploidies, especially in cases where the aforementioned risk factors are prevalent. Multiple platforms are used to detect aneuploidies in embryos, and the NGS is the most widely applied worldwide due to its throughput, its ability to precisely detect mosaicism and segmental mutation, and its capability of concomitant PGT-A and monogenic disorders. Finally, non-invasive preimplantation genetic testing has become more relevant and successful, with acceptable detection rates of embryonic DNA in blastocel fluid and high concordance rates; however, further studies are required to evaluate its concurrence with the detection of genetic abnormalities, such as trisomy 21.

\section{CONFLICT OF INTERESTS}

The authors declare that there are not conflict of interest related to this paper.

\author{
Correspondence author: \\ Javier García-Ferreyra \\ Laboratory of Assisted Reproduction \\ Embryo Fertility Reproductive Biomedicine \\ Lima, Peru \\ E-mail: jgarciaferreyra@embryofertility.com
}

\section{REFERENCES}

AbdelHafez FF, Desai N, Abou-Setta AM, Falcone T, Goldfarb J. Slow freezing, vitrification and ultra-rapid freezing of human embryos: a systematic review and meta-analysis. Reprod Biomed Online. 2010;20:209-22. PMID: 20113959 DOI: $10.1016 /$ j.rbmo.2009.11.013

Aivazidis S, Coughlan CM, Rauniyar AK, Jiang $\mathrm{H}$, Liggett LA, Maclean KN, Roede JR. The burden of trisomy 21 disrupts the proteostasis network in Down syndrome. PLoS One. 2017;21:e0176307. PMID: 28430800 DOI: 10.1371/ journal.pone.0176307

Allen EG, Freeman SB, Druschel C, Hobbs CA, O'Leary LA, Romitti PA, Royle MH, Torfs CP, Sherman SL. Maternal age and risk for trisomy 21 assessed by the origin of chromosome nondisjunction: a report from the Atlanta and National Down Syndrome Projects. Hum Genet. 2009;125:41-52. PMID: 19050929 DOI: 10.1007/s00439-008-0603-8

Andreescu NI, Cosma M, Farcaş SS, Stoian M, Amzăr DG, Puiu M. Assessment of chromosomal aneuploidies in sperm of infertile males by using FISH technique. Rom J Morphol Embryol. 2016;57:173-8. PMID: 27151704

Ata B, Kaplan B, Danzer H, Glassner M, Opsahl M, Tan SL, Munné S. Array $\mathrm{CGH}$ analysis shows that aneuploidy is not related to the number of embryos generated. Reprod Biomed Online. 2012;24:614-20. PMID: 22503277 DOI: 10.1016/j.rbmo.2012.02.009

Baart EB, Martini E, Eijkemans MJ, Van Opstal D, Beckers NG, Verhoeff A, Macklon NS, Fauser BC. Milder ovarian stimulation for in-vitro fertilization reduces aneuploidy in the human preimplantation embryo: a randomized controlled trial. Hum Reprod. 2007;22:980-8. PMID: 17204525 DOI: $10.1093 /$ humrep/del484

Ball MP, Li JB, Gao Y, Lee JH, LeProust EM, Park IH, Xie B, Daley GQ, Church GM. Targeted and genome-scale strategies reveal gene-body methylation signatures in human cells. Nat Biotechnol. 2009;27:361-8. PMID: 19329998 DOI: $10.1038 / \mathrm{nbt} .1533$

Barash OO, Hinckley MD, Rosenbluth EM, Ivani KA, Weckstein LN. High gonadotropin dosage does not affect euploidy and pregnancy rates in IVF PGS cycles with single embryo transfer. Hum Reprod. 2017;32:2209-17. PMID: 29040519 DOI: 10.1093/humrep/dex299 
Bernal DP, Chang CC, Colturato LF, Leef DM, Kort HI, Nagy $Z P$. Evaluation of blastocyst recuperation, implantation and pregnancy rates after vitrification/warming or slow freezing/ thawing cycles. Fertil Steril. 2008;90:S277-8. DOI: 10.1016/j.fertnstert.2008.07.1078

Bielanska M, Tan SL, Ao A. Chromosomal mosaicism throughout human preimplantation development in vitro: incidence, type, and relevance to embryo outcome. Hum Reprod. 2002;17:4139. PMID: 11821287 DOI: $10.1093 /$ humrep/17.2.413

Bingol B, Abike F, Gedikbasi A, Tapisiz OL, Gunenc Z. Comparison of chromosomal abnormality rates in ICSI for nonmale factor and spontaneous conception. J Assist Reprod Genet. 2012;29:25-30. PMID: 22038381 DOI: 10.1007/ s10815-011-9646-1

Bird A. Perceptions of epigenetics. Nature. 2007;447:3968. PMID: 17522671 DOI: $10.1038 /$ nature 05913

Capalbo A, Rienzi L. Mosaicism between trophectoderm and inner cell mass. Fertil Steril. 2017;107:1098106. PMID: 28433375 DOI: $10.1016 /$ j.fertnstert.2017.03.023

Capalbo A, Ubaldi FM, Rienzi L, Scott R, Treff N. Detecting mosaicism in trophectoderm biopsies: current challenges and future possibilities. Hum Reprod. 2017;32:492-8. PMID: 27738115 DOI: 10.1093/humrep/dew250

Capalbo A, Romanelli V, Poli M, Cimadomo D, Ubaldi F, Rienzi L. Non invasive analysis of the embryonic genome: a critical review of non invasive approaches for PGD and PGS. Reprod Biomed Online. 2018;36:e7-e8. DOI: 10.1016/j.rbmo.2017.10.018

Carrasquillo RJ, Kohn TP, Cinnioglu C, Rubio C, Simon C, Ramasamy R, Al-Asmar N. Advanced paternal age does not affect embryo aneuploidy following blastocyst in egg donor cycles. J Assist Reprod Genet. 2019;36:2039-45. PMID: 31385121 DOI: $10.1007 / \mathrm{s} 10815-019-01549-\mathrm{z}$

Chamayou S, Sicali M, Alecci C, Ragolia C, Liprino A, Nibali D, Storaci G, Cardea A, Guglielmino A. The accumulation of vitrified oocytes is a strategy to increase the number of euploid available blastocysts for transfer after preimplantation genetic testing. J Assist Reprod Genet. 2017;34:47986. PMID: 28070710 DOI: $10.1007 /$ s10815-016-0868-0

Check JH. Mild ovarian stimulation. J Assist Reprod Genet. 2007;24:621-7. PMID: 18058016 DOI: $10.1007 /$ s10815$007-9179-9$

Chen C. Pregnancy after human oocyte cryopreservation. Lancet. 1986;327:884-6. PMID: 2870356 DOI: 10.1016/ s0140-6736(86)90989-x

Chiang T, Schultz RM, Lampson MA. Meiotic origins of maternal age-related aneuploidy. Biol Reprod. 2012;86:1-7. PMID: 21957193 DOI: 10.1095/biolreprod.111.094367

Ciccarone F, Valentini E, Malavolta M, Zampieri M, Bacalini MG, Calabrese R, Guastafierro T, Reale A, Franceschi C, Capri M, Breusing N, Grune T, Moreno-Villanueva M, Bürkle A, Caiafa P. DNA Hydroxymethylation Levels Are Altered in Blood Cells From Down Syndrome Persons Enrolled in the MARKAGE Project. J Gerontol A Biol Sci Med Sci. 2018a;73:737-44. PMID: 29069286 DOI: 10.1093/gerona/glx198
Ciccarone F, Tagliatesta S, Caiafa P, Zampieri M. DNA methylation dynamics in aging: how far are we from understanding the mechanisms? Mech Ageing Dev. 2018b;174:3-17.PMID: 29268958 DOI: $10.1016 / j$. mad.2017.12.002

Cimadomo D, Fabozzi G, Vaiarelli A, Ubaldi N, Ubaldi FM, Rienzi L. Impact of Maternal Age on Oocyte and Embryo Competence. Front Endocrinol. 2018;9:327. PMID: 30008696 DOI: $10.3389 /$ fendo.2018.00327

Coates A, Hesla JS, Hurliman A, Coate B, Holmes E, Matthews R, Mounts EL, Turner KJ, Thornhill AR, Griffin DK. Use of suboptimal sperm increases the risk of aneuploidy of the sex chromosomes in preimplantation blastocyst embryos. Fertil Steril. 2013;104:866-72. PMID: 26183314 DOI: $10.1016 /$ j.fertnstert.2015.06.033

Coban O, Serdarogullari M, Onar Sekerci Z, Bilgin EM, Serakinci $N$. Evaluation of the impact of sperm morphology on embryo aneuploidy rates in a donor oocyte program. Syst Biol Reprod Med. 2018;64:169-73. PMID: 29353506 DOI: $10.1080 / 19396368.2018 .1428384$

Cobo A, Meseguer M, Remohí J, Pellicer A. Use of cryobanked oocytes in an ovum donation programme: a prospective, randomized, controlled, clinical trial. Hum Reprod. 2010;25:2239-46. PMID: 20591872 DOI: 10.1093/ humrep/deq146

Coppedè F. Risk factors for Down syndrome. Arch Toxicol. 2016;90:2917-29. PMID: 27600794 doi: 10.1007/ s00204-016-1843-3

Corona-Rivera JR, Martínez-Macías FJ, Bobadilla-Morales L, Corona-Rivera A, Peña-Padilla C, Rios-Flores IM, Flores-Guevara PA, Orozco-Vela M, Aranda-Sánchez CI, Brukman-Jiménez SA. Prevalence and risk factors for Down syndrome: A hospital-based single-center study in Western Mexico. Am J Med Genet A. 2019;179:435-41. PMID: 30666778 DOI: 10.1002/ajmg.a.61044

Dailey T, Dale B, Cohen J, Munné S. Association between nondisjunction and maternal age in meiosis-II human oocytes. Am J Hum Genet. 1996;59:176-84. PMID: 8659524

de Boer KA, Catt JW, Jansen RP, Leigh D, McArthur S. Moving to blastocyst biopsy for preimplantation genetic diagnosis and single embryo transfer at Sydney IVF. Fertil Steril. 2004;82:295-8. PMID: 15302271 DOI: $10.1016 / j$. fertnstert.2003.11.064

De Munck N, El Khatib I, Abdala A, El-Damen A, Bayram A, Arnanz A, Melado L, Larenz B, Fatemi HM. Intracytoplasmic sperm injection is not superior to conventional IVF in couples with non-male factor infertility and preimplantation genetic testing for aneuploidies (PGT-A). Hum Reprod. 2020;35:317-27. PMID: 32086522 DOI: 10.1093/ humrep/deaa002

Deans C, Maggert KA. What do you mean, "epigenetic"? Genetics. 2015;199:887-96. PMID: 25855649 DOI: $10.1534 /$ genetics.114.173492

Devlin L, Morrison PJ. Mosaic Down's syndrome prevalence in a complete population study. Arch Dis Child. 2004;89:1177-8. PMID: 15557061 DOI: 10.1136/ adc. 2003.031765 
Do C, Xing Z, Yu YE, Tycko B. Trans-acting epigenetic effects of chromosomal aneuploidies: lessons from Down syndrome and mouse models. Epigenomics. 2017;9:189207. PMID: 27911079 DOI: $10.2217 /$ epi-2016-0138

Dolgushina NV, Syrkasheva AG, Makarova NP, Kovalskaya EV, Kalinina EA, Sukhikh GT. Correlation between oocyte morphology and the embryo aneuploidy rate in IVF cycles. Gynecol Endocrinol. 2015;31:61-4. DOI: 10.3109/09513590.2015.1086511

Down JL. Observations on an ethnic classification of idiots. 1866. Ment Retard. 1995;33:54-6. PMID: 7707939

Dumanski JP, Piotrowski A. Structural genetic variation in the context of somatic mosaicism. Methods Mol Biol. 2012;838:24972. PMID: 22228016 DOI: $10.1007 / 978-1-61779-507-7 \_12$

Duncan FE, Hornick JE, Lampson MA, Schultz RM, Shea LD, Woodruff TK. Chromosome cohesion decreases in human eggs with advanced maternal age. Aging Cell. 2012;11:1121-4. PMID: 22823533 DOI: $10.1111 / j .1474-$ 9726.2012.00866.x

Edgar DH, Gook DA. A critical appraisal of cryopreservation (slow cooling versus vitrification) of human oocytes and embryos. Hum Reprod Update. 2012;18:536-54. PMID: 22537859 DOI: 10.1093/humupd/dms016

Egozcue J, Santaló J, Giménez C, Pérez N, Vidal F. Preimplantation genetic diagnosis. Mol Cell Endocrinol. 2000;166:21-5. PMID: 10989204. DOI: 10.1016/s03037207(00)00293-8.

Evsikov S, Verlinsky Y. Mosaicism in the inner cell mass of human blastocysts. Hum Reprod. 1998;13:3151-5. PMID: 9853873 DOI: 10.1093/humrep/13.11.3151

Flores-Ramírez F, Palacios-Guerrero C, García-Delgado C, Morales-Jiménez AB, Arias-Villegas CM, Cervantes $A$, Morán-Barroso VF. Cytogenetic profile in 1,921 cases of trisomy 21 syndrome. Arch Med Res. 2015;46:484-9. PMID: 26314225 DOI: 10.1016/j.arcmed.2015.08.001

Forman EJ, Li X, Ferry KM, Scott K, Treff NR, Scott RT Jr. Oocyte vitrification does not increase the risk of embryonic aneuploidy or diminish the implantation potential of blastocysts created after intracytoplasmic sperm injection: a novel, paired randomized controlled trial using DNA fingerprinting. Fertil Steril. 2012;98:644-9. PMID: 22608316 DOI: $10.1016 /$ j.fertnstert.2012.04.028

Fragouli E, Wells D, Delhanty JD. Chromosome abnormalities in the human oocyte. Cytogenet Genome Res. 2011;133:10718. PMID: 21273765 DOI: $10.1159 / 000323801$

Fragouli E, Alfarawati S, Spath K, Wells D. Morphological and cytogenetic assessment of cleavage and blastocyst stage embryos. Mol Hum Reprod. 2014;20:117-26. PMID: 24184690 DOI: $10.1093 / \mathrm{molehr} /$ gat073

Friedenthal J, Maxwell SM, Munné S, Kramer Y, McCulloh $\mathrm{DH}$, McCaffrey C, Grifo JA. Next generation sequencing for preimplantation genetic screening improves pregnancy outcomes compared with array comparative genomic hybridization in single thawed euploid embryo transfer cycles. Fertil Steril. 2018;109:627-32. PMID: 29605407 DOI: $10.1016 /$ j.fertnstert.2017.12.017
Galander S, Barton RE, Kelly DA, Marston AL. Spo13 prevents premature cohesin cleavage during meiosis. Wellcome Open Res. 2019;4:29. PMID: 30906881 DOI: 10.12688/wellcomeopenres.15066.2

García JI, Noriega-Portella L, Noriega-Hoces L. Efficacy of oocyte vitrification combined with blastocyst stage transfer in an egg donation program. Hum Reprod. 2011;26:782-90. PMID: 21303777 DOI: 10.1093/humrep/der008

García-Ferreyra J, Luna D, Villegas L, Romero R, Zavala P, Hilario R, Dueñas-Chacón J. High Aneuploidy Rates Observed in Embryos Derived from Donated Oocytes are Related to Male Aging and High Percentages of Sperm DNA Fragmentation. Clin Med Insights Reprod Health. 2015;9:21-7. PMID: 26604851 DOI: $10.4137 /$ CMRH.S32769

García-Ferreyra J, Hilario R, Dueñas J. High percentages of embryos with 21,18 or 13 trisomy are related to advanced paternal age in donor egg cycles. JBRA Assist Reprod. 2018;22:26-34. PMID: 29303233 DOI: 10.5935/15180557.20180004

Gardner DK, Sheehan CB, Rienzi L, Katz-Jaffe M, Larman MG. Analysis of oocyte physiology to improve cryopreservation procedures. Theriogenology. 2007;67:64-72. PMID: 17049589 DOI: $10.1016 /$ j.theriogenology.2006.09.012

Gensous N, Franceschi C, Salvioli S, Garagnani P, Bacalini MG. Down Syndrome, Ageing and Epigenetics. Subcell Biochem. 2019;91:161-93. PMID: 30888653 DOI: 10.1007/978-981-13-3681-2_7

Ghosh S, Feingold E, Dey SK. Etiology of Down syndrome: Evidence for consistent association among altered meiotic recombination, nondisjunction, and maternal age across populations. Am J Med Genet A. 2009;149A:1415-20. PMID: 19533770 DOI: 10.1002/ajmg.a.32932

Goldman KN, Kramer Y, Hodes-Wertz B, Noyes N, McCaffrey C, Grifo JA. Long-term cryopreservation of human oocytes does not increase embryonic aneuploidy. Fertil Steril. 2015;103:662-8. PMID: 25542819 DOI: 10.1016/j.fertnstert.2014.11.025

Gorbsky GJ. The spindle checkpoint and chromosome segregation in meiosis. FEBS J. 2015;282:2471-87. PMID: 25470754 DOI: $10.1111 /$ febs. 13166

Gug C, Rațiu A, Navolan D, Drăgan I, Groza IM, Păpurică M, Vaida MA, Mozoș I, Jurcă MC. Incidence and Spectrum of Chromosome Abnormalities in Miscarriage Samples: A Retrospective Study of 330 Cases. Cytogenet Genome Res. 2019;158:171-83. PMID: 31434098 DOI: $10.1159 / 000502304$

Hassold T, Hunt P. To err (meiotically) is human: the genesis of human aneuploidy. Nat Rev Genet. 2001;2:280-91. PMID: 11283700 DOI: $10.1038 / 35066065$

Hattori M, Fujiyama A, Taylor TD, Watanabe H, Yada T, Park HS, Toyoda A, Ishii K, Totoki Y, Choi DK, Groner Y, Soeda E, Ohki M, Takagi T, Sakaki Y, Taudien S, Blechschmidt K, Polley A, Menzel U, Delabar J, et al. Chromosome 21 mapping and sequencing consortium. The DNA sequence of human chromosome 21. Nature. 2000;405:311-9. PMID: 10830953 DOI: $10.1038 / 35012518$ 
Hauf S, Watanabe Y. Kinetochore orientation in mitosis and meiosis. Cell. 2004;119:317-27. PMID: 15507205 DOI: $10.1016 / j$. cell.2004.10.014

Heller CG, Clermont Y. Spermatogenesis in man: an estimate of its duration. Science. 1963;140:184-6. PMID: 13953583 DOI: $10.1126 /$ science. 140.3563 .184

Heller CG, Clermont Y. Kinetics of the germinal epithelium in man. Recent Prog Horm Res. 1964;20:545-75. PMID: 14285045

Henderson SA, Edwards RG. Chiasma frequency and maternal age in mammals. Nature. 1968;218:22-8. PMID: 4230650 DOI: $10.1038 / 218022 \mathrm{a} 0$

Ho SS, O'Donoghue K, Choolani M. Fetal cells in maternal blood: state of the art for non-invasive prenatal diagnosis. Ann Acad Med Singap. 2003;32:597-603. PMID: 14626786

Horvath S. DNA methylation age of human tissues and cell types. Genome Biol. 2013;14:R115. PMID: 24138928 DOI: $10.1186 / g b-2013-14-10-r 115$

Huang JY, Chen HY, Tan SL, Chian RC. Effect of choline-supplemented sodium-depleted slow freezing versus vitrification on mouse oocyte meiotic spindles and chromosome abnormalities. Fertil Steril. 2007;88:1093-100. PMID: 17544423 DOI: $10.1016 /$ j.fertnstert.2006.12.066

Huang J, Yan L, Lu S, Zhao N, Xie XS, Qiao J. Validation of next-generation sequencing-based protocol for 24-chromosome aneuploidy screening of blastocysts. Fertil Steril. 2016;105:1532-6. PMID: 26902859 DOI: 10.1016/j.fertnstert.2016.01.040

Hultén MA, Patel SD, Tankimanova $M$, Westgren M, Papadogiannakis N, Jonsson AM, Iwarsson E. On the origin of trisomy 21 Down syndrome. Mol Cytogenet. 2008;1:21. PMID: 18801168 DOI: 10.1186/1755-8166-1-21

Hultén MA, Patel $S$, Jonasson J, Iwarsson E. On the origin of the maternal age effect in trisomy 21 Down syndrome: the Oocyte Mosaicism Selection model. Reproduction. 2010;139:1-9. PMID: 19755486 DOI: 10.1530/REP-09-0088

Hultén MA, Jonasson J, Iwarsson E, Uppal P, Vorsanova SG, Yurov YB, Iourov IY. Trisomy 21 mosaicism: we may all have a touch of Down syndrome. Cytogenet Genome Res. 2013;139:18992. PMID: 23306383 DOI: $10.1159 / 000346028$

Iwarsson E, Kvist U, Hultén MA. Disomy 21 in spermatozoa and the paternal origin of trisomy 21 Down syndrome. Mol Cytogenet. 2015;8:67. PMID: 26300975 DOI: 10.1186/ s13039-015-0155-2

Jenkins EC, Velinov MT, Ye L, Gu H, Li S, Jenkins EC Jr, Brooks SS, Pang D, Devenny DA, Zigman WB, Schupf $\mathrm{N}$, Silverman WP. Telomere shortening in T lymphocytes of older individuals with Down syndrome and dementia. Neurobiol Aging. 2006;27:941-5. PMID: 16046031 DOI: $10.1016 /$ j.neurobiolaging.2005.05.021

Jin S, Lee YK, Lim YC, Zheng Z, Lin XM, Ng DP, Holbrook JD, Law HY, Kwek KY, Yeo GS, Ding C. Global DNA hypermethylation in down syndrome placenta. PLoS Genet. 2013;9:e1003515. PMID: 23754950 DOI: 10.1371/ journal.pgen.1003515
Jones KT. Meiosis in oocytes: predisposition to aneuploidy and its increased incidence with age. Hum Reprod Update. 2008;14:143-58. PMID: 18084010 DOI: 10.1093/ humupd/dmm043

Jones KT, Lane SI. Molecular causes of aneuploidy in mammalian eggs. Development. 2013;140:3719-30. PMID: 23981655 DOI: 10.1242/dev.090589

Kalpana V, Ram P, Soujanya P, Anuradha A, Kusuma BP, Bharati U. Robertsonian Translocations $\mathrm{t}(21 \mathrm{q} ; 21 \mathrm{q})$ and $\mathrm{t}(14 \mathrm{q} ; 21 \mathrm{q})$ in Down Syndrome. Int J Med Res Health Sci. 2017;6:53-8.

Karmiloff-Smith A, Al-Janabi T, D'Souza H, Groet J, Massand E, Mok K, Startin C, Fisher E, Hardy J, Nizetic D, Tybulewicz V, Strydom A. The importance of understanding individual differences in Down syndrome. F1000Res. 2016;5:F1000 Faculty Rev-389. PMID: 27019699 DOI: 10.12688/f1000research.7506.1

Kokkali G, Vrettou C, Traeger-Synodinos J, Jones GM, Cram DS, Stavrou D, Trounson AO, Kanavakis E, Pantos $\mathrm{K}$. Birth of a healthy infant following trophectoderm biopsy from blastocysts for PGD of B-thalassaemia major: Case report. Hum Reprod. 2005;20:1855-9. PMID:15878929 DOI: $10.1093 /$ humrep/deh893

Kurtovic-Kozaric A, Mehinovic $L$, Malesevic R, Mesanovic S, Jaros T, Stomornjak-Vukadin M, Mackic-Djurovic M, Ibrulj $S$, Kurtovic-Basic I, Kozaric M. Ten-year trends in prevalence of Down syndrome in a developing country: impact of the maternal age and prenatal screening. Eur J Obstet Gynecol Reprod Biol. 2016;206:79-83. PMID: 27639605 DOI: $10.1016 /$ j.ejogrb.2016.08.038

Kusre G, Sarma M, Nirmolia T, Shankarishan P. Robertsonian translocation $\mathrm{T}(21 ; 21)$ in a female born to normal parents: a case report. J Clin Diagn Res. 2015;9:GD01-2. PMID: 25738006 DOI: 10.7860/JCDR/2015/10638.5372

Lamb NE, Yu K, Shaffer J, Feingold E, Sherman SL. Association between maternal age and meiotic recombination for trisomy 21. Am J Hum Genet. 2005;76:91-9. PMID: 15551222 DOI: $10.1086 / 427266$

Lara-Gonzalez P, Westhorpe FG, Taylor SS. The spindle assembly checkpoint. Curr Biol. 2012;22:R966-80. PMID: 23174302 DOI: $10.1016 /$ j.cub.2012.10.006

Lejeune J, Gautier M, Turpin R. Study of somatic chromosomes from 9 mongoloid children. C R Hebd Seances Acad Sci. 1959;248:1721-2. PMID: 13639368

Levi-Setti PE, Patrizio P, Scaravelli G. Evolution of human oocyte cryopreservation: slow freezing versus vitrification. Curr Opin Endocrinol Diabetes Obes. 2016;23:445-50. PMID: 27653002 DOI: 10.1097/MED.0000000000000289

Li X, Ouyang Y, Yi Y, Tan Y, Lu G. Correlation analysis between ultrasound findings and abnormal karyotypes in the embryos from early pregnancy loss after in vitro fertilization-embryo transfer. J Assist Reprod Genet. 2017;34:4350. PMID: 27796806 DOI: 10.1007/s10815-016-0821-2

Liñán A, Lawrenz B, El Khatib I, Bayram A, Arnanz A, Rubio C, Chopra R, Fatemi HM. Clinical reassessment of human embryo ploidy status between cleavage and blastocyst stage by Next Generation Sequencing. PLoS One. 2018;13:e0201652. PMID: 30133476 DOI: 10.1371/journal.pone.0201652 
Loane M, Morris JK, Addor MC, Arriola L, Budd J, Doray B, Garne E, Gatt M, Haeusler M, Khoshnood B, Klungsøyr Melve K, Latos-Bielenska A, McDonnell B, Mullaney C, O'Mahony M, Queisser-Wahrendorf A, Rankin J, Rissmann A, Rounding C, Salvador J, et al. Twenty-year trends in the prevalence of Down syndrome and other trisomies in Europe: impact of maternal age and prenatal screening. Eur J Hum Genet. 2013;21:27-33. PMID: 22713804 DOI: 10.1038/ejhg.2012.94

López-Otín C, Blasco MA, Partridge L, Serrano M, Kroemer G. The hallmarks of aging. Cell. 2013;153:1194-217. PMID: 23746838 DOI: $10.1016 /$ j.cell.2013.05.039

Lott IT, Head E. Alzheimer disease and Down syndrome: factors in pathogenesis. Neurobiol Aging. 2005;26:383-9. PMID: 15639317 DOI: $10.1016 /$ j.neurobiolaging.2004.08.005

Lubis HP, Wiweko B, Iffanolida PA, Mutia K, Riayati O, Mansyur E. Poor oocytes increase the risk of aneuploidy embryos. Adv Sci Lett. 2017;23:6866-70. DOI: 10.1166/ asl.2017.9419

Lyle R, Béna F, Gagos S, Gehrig C, Lopez G, Schinzel A, Lespinasse J, Bottani A, Dahoun S, Taine L, Doco-Fenzy M, Cornillet-Lefèbvre $P$, Pelet $A$, Lyonnet $S$, Toutain $A$, Colleaux $L$, Horst J, Kennerknecht I, Wakamatsu N, Descartes M, et al. Genotype-phenotype correlations in Down syndrome identified by array $\mathrm{CGH}$ in 30 cases of partial trisomy and partial monosomy chromosome 21. Eur J Hum Genet. 2009; 17:45466. PMID: 19002211 DOI: 10.1038/ejhg.2008.214

Magli MC, Gianaroli L, Ferraretti AP, Gordts S, Fredericks V, Crippa A. Paternal contribution to aneuploidy in preimplantation embryos. Reprod Biomed Online. 2009;18:536-42. PMID: 19400996 DOI: 10.1016/s1472-6483(10)60131-9

Mastenbroek S, Twisk M, van der Veen F, Repping S. Preimplantation genetic screening: a systematic review and meta-analysis of RCTs. Hum Reprod Update. 2011;14:45466. PMID: 21531751 DOI: 10.1093/humupd/dmr003

McArthur SJ, Leigh D, Marshall JT, de Boek KA, Jansen RP. Pregnancies and live births after trophectoderm biopsy and preimplantation genetic testing of human blastocysts. Fertil Steril. 2005;84:1628-36. PMID: 16359956 DOI: $10.1016 /$ j.fertnstert.2005.05.063

Mertzanidou A, Wilton L, Cheng J, Spits C, Vanneste E, Moreau $Y$, Vermeesch JR, Sermon K. Microarray analysis reveals abnormal chromosomal complements in over $70 \%$ of 14 normally developing human embryos. Hum Reprod. 2013;28:256-64. PMID: 23054067 DOI: 10.1093/humrep/des362

Mills M, Rindfuss RR, McDonald P, Te Velde E; ESHRE Reproduction and Society Task Force. Why do people postpone parenthood? Reasons and social policy incentives. Hum Reprod Update. 2011;17:848-60. PMID: 21652599 DOI: $10.1093 /$ humupd/dmr026

Misell LM, Holochwost D, Boban D, Santi N, Shefi S, Hellerstein MK, Turek PJ. A stable isotope-mass spectrometric method for measuring human spermatogenesis kinetics in vivo. J Urol. 2006;175:242-6; discussion 246. PMID: 16406920 DOI: $10.1016 /$ S0022-5347(05)00053-4
Modi D, Berde P, Bhartiya D. Down syndrome: a study of chromosomal mosaicism. Reprod Biomed Online. 2003;6:499-503. PMID: 12831601 DOI: $10.1016 /$ s14726483(10)62174-8

Munné S, Alikani M, Tomkin G, Grifo J, Cohen J. Embryo morphology, developmental rates, and maternal age are correlated with chromosome abnormalities. Fertil Steril. 1995;64:382-91. PMID: 7615118

Munné S, Escudero T, Colls P, Xuezhong Z, Oter M, Garrisi M, Barnes F, Zouves C, Werlin L, Magli C, Cohen J. Predictability of preimplantation genetic diagnosis of aneuploidy and translocations on prospective attempts. Reprod Biomed Online. 2004;9:645-51. PMID: 15670413 DOI: $10.1016 /$ s1472-6483(10)61775-0

Munné S, Chen S, Colls P, Garrisi J, Zheng X, Cekleniak N, Lenzi M, Hughes P, Fischer J, Garrisi M, Tomkin G, Cohen J. Maternal age, morphology, development and chromosome abnormalities in over 6000 cleavage-stage embryos. Reprod Biomed Online. 2007;14:628-34. PMID: 17509208 DOI: $10.1016 /$ s1472-6483(10)61057-7

Munné S, Alikani M, Ribustello L, Colls P, Martínez-Ortiz PA, McCulloh DH; Referring Physician Group. Euploidy rates in donor egg cycles significantly differ between fertility centers. Hum Reprod. 2017a;32:743-9. PMID: 28333245 DOI: $10.1093 /$ humrep/dex031

Munné S, Blazek J, Large M, Martinez-Ortiz PA, Nisson $\mathrm{H}$, Liu E, Tarozzi N, Borini A, Becker A, Zhang J, Maxwell S, Grifo J, Babariya D, Wells D, Fragouli E. Detailed investigation into the cytogenetic constitution and pregnancy outcome of replacing mosaic blastocysts detected with the use of high-resolution next-generation sequencing. Fertil Steril. 2017b;108:62-71.e8. PMID: 28579407 DOI: 10.1016/j. fertnstert.2017.05.002

Musacchio A. The Molecular Biology of Spindle Assembly Checkpoint Signaling Dynamics. Curr Biol. 2015;25:R100218. PMID: 26485365 DOI: 10.1016/j.cub.2015.08.051

Nabti I, Grimes R, Sarna H, Marangos P, Carroll J. Maternal age-dependent APC/C-mediated decrease in securin causes premature sister chromatid separation in meiosis II. Nat Commun. 2017;8:15346. PMID: 28516917 DOI: 10.1038/ ncomms 15346

Nagaoka SI, Hassold TJ, Hunt PA. Human aneuploidy: mechanisms and new insights into an age-old problem. Nat Rev Genet. 2012;13:493-504. PMID: 22705668 DOI: $10.1038 / \mathrm{nrg} 3245$

Nagy ZP, Nel-Themaat L, Chang CC, Shapiro DB, Berna DP. Cryopreservation of eggs. Methods Mol Biol. 2014;1154:439-54. PMID: 24782022. DOI: 10.1007/9781-4939-0659-8_20

Nottola SA, Macchiarelli G, Coticchio G, Bianchi S, Cecconi S, De Santis L, Scaravelli G, Flamigni C, Borini A. UItrastructure of human mature oocytes after slow cooling cryopreservation using different sucrose concentrations. Hum Reprod. 2007;22:1123-33. PMID: 17158818 DOI: $10.1093 /$ humrep/del463 
Noyes N, Reh A, McCaffrey C, Tan O, Krey L. Impact of developmental stage at cryopreservation and transfer on clinical outcome of frozen embryo cycles. Reprod Biomed Online. 2009;19:9-15. PMID: 20034419 DOI: 10.1016/ s1472-6483(10)60279-9

Nybo Andersen AM, Wohlfahrt J, Christens P, Olsen J, Melbye M. Maternal age and fetal loss: population based register linkage study. BMJ. 2000;320:1708-12. PMID: 10864550 DOI: $10.1136 / \mathrm{bmj} .320 .7251 .1708$

Obeid R, Hartmuth K, Herrmann W, Gortner L, Rohrer TR, Geisel J, Reed MC, Nijhout HF. Blood biomarkers of methylation in Down syndrome and metabolic simulations using a mathematical model. Mol Nutr Food Res. 2012;56:1582-9. PMID: 22930479 DOI: 10.1002/mnfr.201200162

Obermann-Borst SA, van Driel LM, Helbing WA, de Jonge $R$, Wildhagen MF, Steegers EA, Steegers-Theunissen RP. Congenital heart defects and biomarkers of methylation in children: a case-control study. Eur J Clin Invest. 2011;41:143-50. PMID: 20868449 DOI: $10.1111 / \mathrm{j} .1365-$ 2362.2010.02388.x

Oliver TR, Feingold E, Yu K, Cheung V, Tinker S, Yadav-Shah $M$, Masse N, Sherman SL. New insights into human nondisjunction of chromosome 21 in oocytes. PLoS Genet. 2008;4:e1000033. PMID: 18369452 DOI: 10.1371/journal.pgen. 1000033

Oliver TR, Bhise A, Feingold E, Tinker S, Masse N, Sherman SL. Investigation of factors associated with paternal nondisjunction of chromosome 21 . Am J Med Genet A. 2009;149A:1685-90. PMID: 19606484 DOI: 10.1002/ ajmg.a.32942

Oliver TR, Tinker SW, Allen EG, Hollis $\mathrm{N}$, Locke AE, Bean LJ, Chowdhury R, Begum F, Marazita M, Cheung V, Feingold $\mathrm{E}$, Sherman SL. Altered patterns of multiple recombinant events are associated with nondisjunction of chromosome 21. Hum Genet. 2012;131:1039-46. PMID: 22160426 DOI: $10.1007 / \mathrm{s} 00439-011-1121-7$

Orr B, Godek KM, Compton D. Aneuploidy. Curr Biol. 2015;25:R538-42. PMID: 26126276 DOI: 10.1016/j. cub.2015.05.010

Oster-Granite ML, Parisi MA, Abbeduto L, Berlin DS, Bodine C, Bynum D, Capone G, Collier E, Hall D, Kaeser L, Kaufmann P, Krischer J, Livingston M, McCabe LL, Pace J, Pfenninger $K$, Rasmussen SA, Reeves RH, Rubinstein $Y$, Sherman S, et al. Down syndrome: national conference on patient registries, research databases, and biobanks. Mol Genet Metab. 2011;104:13-22. PMID: 21835664 DOI: 10.1016/j.ymgme.2011.07.005

Pagano G, Castello G. Oxidative stress and mitochondrial dysfunction in Down syndrome. Adv Exp Med Biol. 2012;724:291-9. PMID: 22411251 DOI: $10.1007 / 978-1-$ 4614-0653-2_22

Papavassiliou P, York TP, Gursoy N, Hill G, Nicely LV, Sundaram U, McClain A, Aggen SH, Eaves L, Riley B, Jackson-Cook C. The phenotype of persons having mosaicism for trisomy $21 /$ Down syndrome reflects the percentage of trisomic cells present in different tissues. Am J Med Genet A. 2009;149A:57383. PMID: 19291777 DOI: 10.1002/ajmg.a.32729
Papavassiliou P, Charalsawadi C, Rafferty K, Jackson-Cook C. Mosaicism for trisomy 21: a review. Am J Med Genet A. 2015;167A:26-39. PMID: 25412855 DOI: 10.1002/ ajmg.a.36861

Patterson D. Molecular genetic analysis of Down syndrome. Hum Genet. 2009;126:195-214. PMID: 19526251 DOI: $10.1007 / \mathrm{s} 00439-009-0696-8$

Patterson D, Cabelof DC. Down syndrome as a model of DNA polymerase beta haploinsufficiency and accelerated aging. Mech Ageing Dev. 2012;133:133-7. PMID: 22019846 DOI: $10.1016 /$ j.mad.2011.10.001

Pellestor F, Andréo B, Anahory T, Déchaud H, Hédon B, Hamamah S. [The cytogenetics of human oocytes: 40 years of progress]. Gynecol Obstet Fertil. 2005;33:283-92. French. PMID: 15914072 DOI: 10.1016/j.gyobfe.2005.04.003

Pendina AA, Efimova OA, Chiryaeva OG, Tikhonov AV, Petrova LI, Dudkina VS, Sadik NA, Fedorova ID, Galembo IA, Kuznetzova TV, Gzgzyan AM, Baranov VS. A comparative cytogenetic study of miscarriages after IVF and natural conception in women aged under and over 35 years. J Assist Reprod Genet. 2014;31:149-55. PMID: 24322344 DOI: $10.1007 / \mathrm{s} 10815-013-0148-1$

Pertea M, Shumate A, Pertea G, Varabyou A, Breitwieser FP, Chang YC, Madugundu AK, Pandey A, Salzberg SL. CHESS: a new human gene catalog curated from thousands of large-scale RNA sequencing experiments reveals extensive transcriptional noise. Genome Biol. 2018;19:208. PMID: 30486838 DOI: $10.1186 /$ s13059-018-1590-2

Petersen MB, Mikkelsen M. Nondisjunction in trisomy 21 : origin and mechanisms. Cytogenet Cell Genet. 2000;91:199203. PMID: 11173856 DOI: $10.1159 / 000056844$

Pines J. Mitosis: a matter of getting rid of the right protein at the right time. Trends Cell Biol. 2006;16:55-63. PMID: 16337124 DOI: $10.1016 /$ j.tcb.2005.11.006

Qin JZ, Pang LH, Li MQ, Xu J, Zhou X. Risk of chromosomal abnormalities in early spontaneous abortion after assisted reproductive technology: a meta-analysis. PLoS One. 2013;8:e75953. PMID: 24130752 DOI: 10.1371/journal. pone.0075953

Radoń-Pokracka $M$, Adrianowicz B, Płonka $M$, Danił $P$, Nowak M, Huras H. Evaluation of Pregnancy Outcomes at Advanced Maternal Age. Open Access Maced J Med Sci. 2019;7:1951-6. PMID: 31406535 DOI: 10.3889/oamjms.2019.587

Rink BD, Norton ME. Screening for fetal aneuploidy. Semin Perinatol. 2016;40:35-43. PMID: 26725144 DOI: 10.1053/j.semperi.2015.11.006

Roizen NJ, Patterson D. Down's syndrome. Lancet. 2003;361:1281-9. PMID: 12699967 DOI: $10.1016 /$ S01406736(03)12987-X

Rubio C, Rodrigo L, Mercader A, Mateu E, Buendía P, Pehlivan T, Viloria T, De los Santos MJ, Simón C, Remohí J, Pellicer A. Impact of chromosomal abnormalities on preimplantation embryo development. Prenat Diagn. 2007;27:748-56. PMID: 17546708 DOI: $10.1002 / p d .1773$ 
Sailani MR, Santoni FA, Letourneau A, Borel C, Makrythanasis $P$, Hibaoui $Y$, Popadin K, Bonilla X, Guipponi M, Gehrig C, Vannier A, Carre-Pigeon F, Feki A, Nizetic D, Antonarakis SE. DNA-Methylation Patterns in Trisomy 21 Using Cells from Monozygotic Twins. PLoS One. 2015;10:e0135555. PMID: 26317209 DOI: 10.1371/journal.pone.0135555

Saiyed N, Bakshi S, Muthuswamy S, Agarwal S. Young mothers and higher incidence of maternal meiosis-I non- disjunction: Interplay of environmental exposure and genetic alterations during halt phase in trisomy 21. Reprod Toxicol. 2018;79:1-7. PMID: 29702247 DOI: 10.1016/j.reprotox.2018.04.014

Santaguida S, Amon A. Short- and long-term effects of chromosome mis-segregation and aneuploidy. Nat Rev Mol Cell Biol. 2015;16:473-85. Erratum in: Nat Rev Mol Cell Biol. 2015;16:576. PMID: 26204159. DOI: $10.1038 / \mathrm{nrm} 4025$

Scott RT Jr, Ferry K, Su J, Tao X, Scott K, Treff NR. Comprehensive chromosome screening is highly predictive of the reproductive potential of human embryos: a prospective, blinded, non-selection study. Fertil Steril. 2012;97:870-5. PMID: 22305103 DOI: 10.1016/j.fertnstert.2012.01.104

Sekhon L, Shaia K, Santistevan A, Cohn KH, Lee JA, Beim $P Y$, Copperman AB. The cumulative dose of gonadotropins used for controlled ovarian stimulation does not influence the odds of embryonic aneuploidy in patients with normal ovarian response. J Assist Reprod Genet. 2017;34:749-58. PMID: 28321529 DOI: 10.1007/s10815-017-0909-3

Shin M, Siffel C, Correa A. Survival of children with mosaic Down syndrome. Am J Med Genet A. 2010;152A:800-1. PMID: 20186777 DOI: 10.1002/ajmg.a.33295

Sotonica M, Mackic-Djurovic M, Hasic S, Kiseljakovic E, Jadric R, Ibrulj S. Association of Parental Age and the Type of Down Syndrome on the Territory of Bosnia and Herzegovina. Med Arch. 2016;70:88-91. PMID: 27147778 DOI: 10.5455/medarh.2016.70.88-91

Spinella F, Fiorentino F, Biricik A, Bono S, Ruberti A, Cotroneo E, Baldi M, Cursio E, Minasi MG, Greco E. Extent of chromosomal mosaicism influences the clinical outcome of in vitro fertilization treatments. Fertil Steril. 2018;109:77-83. PMID: 29191449 DOI: $10.1016 /$ j.fertnstert.2017.09.025.

Su Y, Li JJ, Wang C, Haddad G, Wang WH. Aneuploidy analysis in day 7 human blastocysts produced by in vitro fertilization. Reprod Biol Endocrinol. 2016;14:20. PMID: 27080232 DOI: 10.1186/s12958-016-0157-x

Takaesu N, Jacobs PA, Cockwell A, Blackston RD, Freeman S, Nuccio J, Kurnit DM, Uchida I, Freeman V, Hassold T. Nondisjunction of chromosome 21. Am J Med Genet Suppl. 1990; 7:17581. PMID: 1981476 DOI: 10.1002/ajmg.1320370735

Tanaka TU. Chromosome bi-orientation on the mitotic spindle. Philos Trans R Soc Lond B Biol Sci. 2005;360:5819. PMID: 15897181 DOI: $10.1098 /$ rstb.2004.1612

Taylor TH, Gitlin SA, Patrick JL, Crain JL, Wilson JM, Griffin DK. The origin, mechanisms, incidence and clinical consequences of chromosomal mosaicism in humans. Hum Reprod Update. 2014;20:571-81. PMID: 24667481 DOI: 10.1093/humupd/dmu016
Teipel SJ, Hampel H. Neuroanatomy of Down syndrome in vivo: a model of preclinical Alzheimer's disease. Behav Genet. 2006;36:405-15. PMID: 16485178 DOI: 10.1007/ s10519-006-9047-x

Templado C, Vidal F, Estop A. Aneuploidy in human spermatozoa. Cytogenet Genome Res. 2011;133:91-9. PMID: 21282942 DOI: $10.1159 / 000323795$

Thompson JA. Disentangling the roles of maternal and paternal age on birth prevalence of down syndrome and other chromosomal disorders using a Bayesian modeling approach. BMC Med Res Methodol. 2019;19:82. PMID: 31014243 DOI: $10.1186 /$ s12874-019-0720-1

Thorne J, Loza A, Kaye L, Nulsen J, Benadiva C, Grow D, Engmann L. Euploidy rates between cycles triggered with gonadotropin-releasing hormone agonist and human chorionic gonadotropin. Fertil Steril. 2019;112:258-65. PMID: 31103285 DOI: $10.1016 /$ j.fertnstert.2019.03.040

Touati SA, Wassmann K. How oocytes try to get it right: spindle checkpoint control in meiosis. Chromosoma. 2016;125:321-35. PMID: 26255654 DOI: 10.1007/ s00412-015-0536-7

Trounson A, Mohr L. Human pregnancy following cryopreservation, thawing and transfer of an eight-cell embryo. Nature. 1983;305:707-9. PMID: 6633637 DOI: $10.1038 / 305707 a 0$

Uroz L, Templado C. Meiotic non-disjunction mechanisms in human fertile males. Hum Reprod. 2012;27:1518-24. PMID: 22381620 DOI: 10.1093/humrep/des051

Van Opstal D, Srebniak MI, Polak J, de Vries F, Govaerts LC, Joosten M, Go AT, Knapen MF, van den Berg C, Diderich KE, Galjaard RJ. False Negative NIPT Results: Risk Figures for Chromosomes 13, 18 and 21 Based on Chorionic Villi Results in 5967 Cases and Literature Review. PLoS One. 2016;11:e0146794. PMID: 26771677 DOI: 10.1371/journal.pone.0146794

Victor AR, Griffin DK, Brake AJ, Tyndall JC, Murphy AE, Lepkowsky LT, Lal A, Zouves CG, Barnes FL, McCoy RC, Viotti M. Assessment of aneuploidy concordance between clinical trophectoderm biopsy and blastocyst. Hum Reprod. 2019;34:181-92. PMID: 30418565 DOI: 10.1093/humrep/dey327

Voullaire L, Slater $H$, Williamson R, Wilton L. Chromosome analysis of blastomeres from human embryos by using comparative genomic hybridization. Hum Genet. 2000;106:2107. PMID: 10746563 DOI: $10.1007 / s 004390051030$

Vraneković J, Božović IB, Grubić Z, Wagner J, Pavlinić D, Dahoun S, Bena F, Culić V, Brajenović-Milić B. Down syndrome: parental origin, recombination, and maternal age. Genet Test Mol Biomarkers. 2012;16:70-3. PMID: 21861707 DOI: $10.1089 / \mathrm{gtmb} .2011 .0066$

Weber S, Haferlach C, Jeromin S, Nadarajah N, Dicker F, Noël L, Zenger M, Alpermann T, Kern W, Haferlach T, Schnittger S. Gain of chromosome 21 or amplification of chromosome arm $21 \mathrm{q}$ is one mechanism for increased ERG expression in acute myeloid leukemia. Genes Chromosomes Cancer. 2016;55:148-57. PMID: 26542308 DOI: $10.1002 /$ gcc. 22321 
Weghofer A, Munné S, Brannath W, Chen S, Tomkin G, Cekleniak N, Garrisi M, Barad D, Cohen J, Gleicher N. The impact of LH-containing gonadotropins on diploidy rates in preimplantation embryos: long protocol stimulation. Hum Reprod. 2008;23:499-503. PMID: 18182396 DOI: 10.1093/humrep/dem412

Weijerman M, de Winter JP. Clinical practice. The care of children with Down syndrome. Eur J Pediatr. 2010;169:1445-52. PMID: 20632187 DOI: 10.1007/ s00431-010-1253-0

Wells D, Delhanty JD. Comprehensive chromosomal analysis of human preimplantation embryos using whole genome amplification and single cell comparative genomic hybridization. Mol Hum Reprod. 2000;6:1055-62. PMID: 11044470 DOI: $10.1093 / \mathrm{molehr} / 6.11 .1055$

Wiseman FK, Al-Janabi T, Hardy J, Karmiloff-Smith A, Nizetic D, Tybulewicz VL, Fisher EM, Strydom A. A genetic cause of Alzheimer disease: mechanistic insights from Down syndrome. Nat Rev Neurosci. 2015;16:564-74. PMID: 26243569 DOI: $10.1038 / n r n 3983$

Witters G, Van Robays J, Willekes C, Coumans A, Peeters H, Gyselaers W, Fryns JP. Trisomy 13, 18, 21, Triploidy and Turner syndrome: the 5T's. Look at the hands. Facts Views Vis Obgyn. 2011;3:15-21. PMID: 24753843

Wu Q, Li H, Zhu Y, Jiang W, Lu J, Wei D, Yan J, Chen ZJ. Dosage of exogenous gonadotropins is not associated with blastocyst aneuploidy or live-birth rates in PGS cycles in Chinese women. Hum Reprod. 2018;33:1875-82. PMID: 30137360 DOI: $10.1093 /$ humrep/dey 270
Yan J, Zhang Q, Chen Y, Chen ZJ. Birth of a Mosaic NonDown Syndrome Offspring to a $45, X Y, t(21 ; 21)(q 10 ; q 10)$ Homologous Robertsonian Translocation Carrier: A Case Report. J Reprod Med. 2017;62:337-41. PMID: 30028100

Yang YH, Kim SH, Yang ES, Kim SK, Kim IK, Park YW, Cho JS, Lee $\mathrm{YH}$. Prenatal diagnosis of fetal trisomy 21 from maternal peripheral blood. Yonsei Med J. 2003;44:181-6. PMID: 12728455 DOI: $10.3349 / y m j .2003 .44 .2 .181$

Yang YH, Yang ES, Kwon JY, Kim IK, Park YW. Prenatal diagnosis of trisomy 21 with fetal cells in maternal blood using comparative genomic hybridization. Fetal Diagn Ther. 2006;21:125-33. PMID: 16354990 DOI: $10.1159 / 000089062$

Ye H, Wu H, Huang H, Liu Y, Zou B, Sun L, Zhou G. Prenatal diagnosis of trisomy 21 by quantitatively pyrosequencing heterozygotes using amniotic fluid as starting material of PCR. Analyst. 2013;138:2443-8. PMID: 23463136 DOI: $10.1039 / c 3 a n 36903 j$

Zeilmaker GH, Alberda AT, van Gent I, Rijkmans CM, Drogendijk AC. Two pregnancies following transfer of intact frozen-thawed embryos. Fertil Steril. 1984;42:293-6. PMID: 6745463 DOI: $10.1016 / s 0015-0282(16) 48029-5$

Zhang L, Yan LY, Zhi X, Yan J, Qiao J. Female fertility: is it safe to "freeze?". Chin Med J. 2015;128:390-7. PMID: 25635437 DOI: $10.4103 / 0366-6999.150115$

Zhu JL, Hasle H, Correa A, Schendel D, Friedman JM, OIsen J, Rasmussen SA. Survival among people with Down syndrome: a nationwide population-based study in Denmark. Genet Med. 2013;15:64-9. PMID: 22878506 DOI: $10.1038 /$ gim. 2012.93 